\title{
Article \\ Effect of Plasmonic Gold Nanoprisms on Biofilm Formation and Heat Shock Proteins Expression in Human Pathogenic Bacteria
}

\author{
Rihab Lagha ${ }^{1,2}$, Fethi Ben Abdallah ${ }^{1,2, *}$, Amine Mezni ${ }^{3}$ and Othman M. Alzahrani ${ }^{1}$ \\ 1 Department of Biology, College of Sciences, Taif University, P.O. Box 11099, Taif 21944, Saudi Arabia; \\ rihab.k@tu.edu.sa (R.L.); o.alzahrani@tu.edu.sa (O.M.A.) \\ 2 Research Unit UR17ES30: Virology and Antiviral Strategies, Higher Institute of Biotechnology, University of \\ Monastir, Monastir 5000, Tunisia \\ 3 Department of Chemistry, College of Sciences, Taif University, P.O. Box 11099, Taif 21944, Saudi Arabia; \\ aminemezni@tu.edu.sa \\ * Correspondence: fetyben@tu.edu.sa
}

Citation: Lagha, R.; Abdallah, F.B.; Mezni, A.; Alzahrani, O.M. Effect of Plasmonic Gold Nanoprisms on Biofilm Formation and Heat Shock Proteins Expression in Human Pathogenic Bacteria. Pharmaceuticals 2021, 14, 1335. https://doi.org/ 10.3390/ph14121335

Academic Editor: Fu-Gen Wu

Received: 26 November 2021 Accepted: 17 December 2021 Published: 20 December 2021

Publisher's Note: MDPI stays neutral with regard to jurisdictional claims in published maps and institutional affiliations.

Copyright: () 2021 by the authors. Licensee MDPI, Basel, Switzerland. This article is an open access article distributed under the terms and conditions of the Creative Commons Attribution (CC BY) license (https:// creativecommons.org/licenses/by/ $4.0 /)$.

\begin{abstract}
Gold nanoparticles have gained interest in biomedical sciences in the areas of nanodiagnostics, bio-labeling, drug delivery, and bacterial infection. In this study, we examined, for the first time, the antibacterial and antibiofilm properties of plasmonic gold nanoprisms against human pathogenic bacteria using MIC and crystal violet. In addition, the expression level of GroEL/GroES heat shock proteins was also investigated by western blot. Gold nanoparticles were characterized by TEM and EDX, which showed equilateral triangular prisms with an average edge length of $150 \mathrm{~nm}$. Antibacterial activity testing showed a great effect of AuNPs against pathogenic bacteria with MICs values ranging from $50 \mu \mathrm{g} / \mathrm{mL}$ to $100 \mu \mathrm{g} / \mathrm{mL}$. Nanoparticles demonstrated strong biofilm inhibition action with a percentage of inhibition ranging from 40.44 to $82.43 \%$. Western blot analysis revealed that GroEL was an AuNPs-inducible protein with an increase of up to $66.04 \%$, but GroES was down-regulated with a reduction of up to $46.81 \%$. Accordingly, plasmonic gold nanoprisms, could be a good candidate for antibiotics substitution in order to treat bacterial infections.
\end{abstract}

Keywords: plasmonic gold nanoprisms; antibacterial; antibiofilm; GroEL/GroES expression; pathogenic bacteria

\section{Introduction}

Pathogenic bacteria are microorganisms that cause infectious diseases. They can transmit from person to person directly or indirectly through animal and insect vectors, as well as through polluted water and food. [1]. Antibiotic therapy continues to lose its effectiveness due to the spread of drug resistance in bacterial pathogens. The infections caused by drug-resistant bacteria result in additional very expensive medical costs [2,3]. Faced with this critical situation, the development of new antibacterial agents and therapeutic strategies is urgently necessary.

Most pathogenic bacteria are resistant to antibacterial compounds due to their capacity to produce biofilm [4]. In addition, the biofilm produced by sessile bacteria is responsible for several chronic diseases [5]. Biofilms formed by pathogenic bacteria are one of their major virulence factors that contribute to $>80 \%$ of human infections [6]. Biofilm is a complex community composed of nucleic acids, lipids, proteins, and polysaccharides [7]. In biofilms, pathogenic bacteria become more persistent in the host environment and more resistant to antibiotics [8,9] that is a major medical problem. Thereby, the discovering of new compounds to combat biofilm is of great importance.

Heat shock proteins (HSPs) are major proteins that may be involved in bacterial biofilm [10]. These HSPs are implicated in the bacterial response to environmental stresses and protect pathogens against phagocytic cells [11]. In bacteria, one of the major molecular chaperones is the GroE machine (GroES and GroEL) [12]. GroEL assists in correct folding 
and assembly of proteins and is involved in diverse cellular processes, including DNA replication, UV mutagenesis, bacterial growth, RNA transcription, and flagella synthesis [13]. GroEL, together with GroES, translocate protein across membrane barriers. These HSPs act by preventing protein denaturation and to reactivate partially denatured proteins [14-17].

Nanoparticles have been used successfully in the delivery of therapeutic agents [18]. Due to their physicochemical properties, nanoparticles become more effective against multidrug-resistant pathogens [19]. AuNPs have gained interest in biomedical sciences due to their low toxicity to human cells, chemical, and biological stability, shape, surface properties, catalytic and antibacterial activities, especially in the areas of nano-diagnostics, bio-labeling, and drug delivery [18]. Safe nanomaterial could be a novel approach to inhibit and/or eradicate biofilm-related bacterial infections. In addition, the penetrating power of nanoparticles plays a major role in their action within the biofilm. In addition, the chance of developing resistance to nanoparticles is lower compared to conventional antibiotics [20].

This work aimed to study the antibacterial and biofilm inhibition properties of plasmonic gold nanoprisms against human pathogenic bacteria. In addition, the expression level of heat shock proteins GroEL and GroES was also investigated.

\section{Results}

\subsection{AuNPs Characterization}

AuNPs were characterized using TEM (Figure 1a) that shows equilateral triangular prisms with an average edge length of $150 \mathrm{~nm}$ (Figure 1b). At a molar ratio of $\mathrm{PVP} / \mathrm{Au}=0.05$, the PVP concentration is sufficient to stabilize the gold nanoparticles. Therefore, the gold nanoparticles nucleate more quickly and form monodisperse triangular gold nanoprisms. According to the energy dispersive spectrum (EDX) analysis, le $\mathrm{Tr}-\mathrm{Au}$ NPs consist of only gold, and the copper element came from a copper grid.

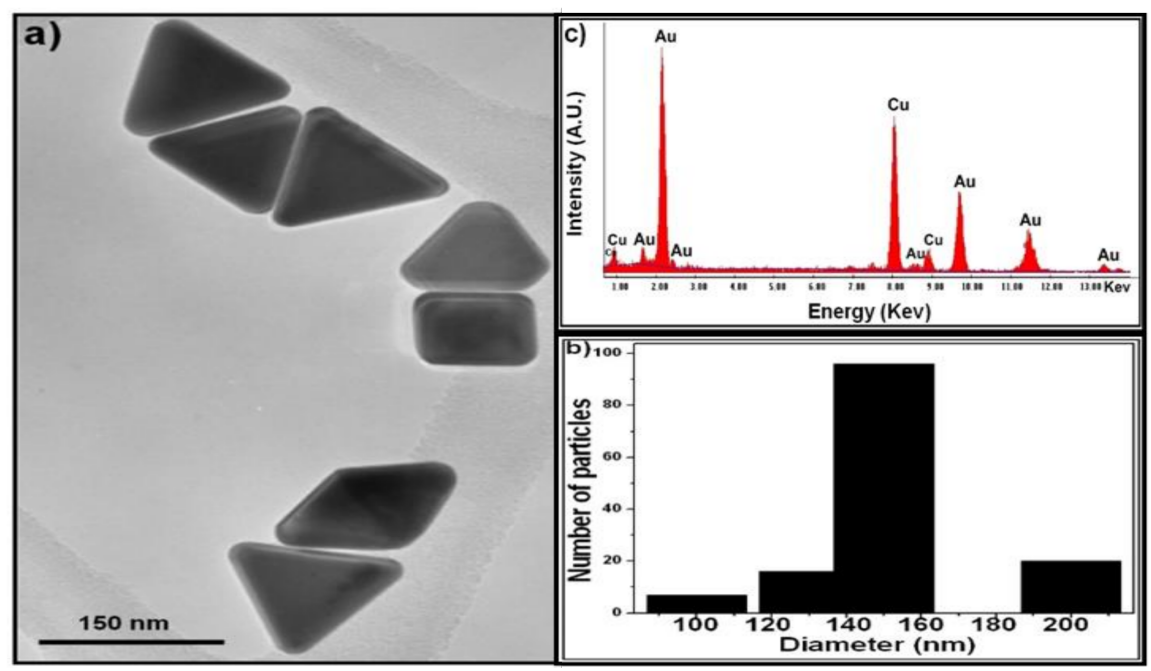

Figure 1. Characterization of AuNPs. (a) TEM image, (b) particle size distribution, and (c) EDX spectrum of triangular gold nanoprisms. Adapted with permission from [21], Copyright 2014 American Chemical Society.

\subsection{Antibacterial Property of AuNPs}

The minimal inhibition concentrations (MICs) and the minimal bactericidal concentrations (MBCs) were used to evaluate the antibacterial activity of AuNPs against the investigated bacteria.

The value of MIC was $50 \mu \mathrm{g} / \mathrm{mL}$ for S. Typhimurium and V. cholerae, and was $100 \mu \mathrm{g} / \mathrm{mL}$ for E. coli, E. faecalis, P. aeruginosa, S. aureus, B. cereus, S. sonnei, and N. gonorrhoeae. However, the MBC values were $0.4 \mathrm{mg} / \mathrm{mL}$ for all the tested bacteria excepted from S. aureus and S. sonnei, which were $0.8 \mathrm{mg} / \mathrm{mL}$. 


\subsection{Biofilm Formation}

Bacteria were evaluated for their ability to produce biofilm on polystyrene surfaces (Table 1). Results showed that almost all of the strains were low-grade positive producers with OD570 values varied from 0.119 to 0.599 . In addition, only S. aureus was a highly positive producer, while $B$. cereus and $V$. cholerae were not able to form biofilms.

Table 1. Antibiofilm activity of AuNPs on polystyrene.

\begin{tabular}{|c|c|c|c|c|c|}
\hline Strains & Control OD570 \pm SD & Biofilm Phenotype & AuNPs OD570 \pm SD & Biofilm Phenotype & Inhibition (\%) \\
\hline S. Typhimurium & $0.37 \pm 0.026$ & low-grade positive & $0.065 \pm 0.073$ & negative & 82.43 \\
\hline B. cereus & $0.046 \pm 0.003$ & negative & - & - & - \\
\hline E. coli & $0.119 \pm 0.042$ & low-grade positive & $0.12 \pm 0.062$ & low-grade positive & 0 \\
\hline E. faecalis & $0.599 \pm 0.067$ & low-grade positive & $0.206 \pm 0.032$ & low-grade positive & 65.60 \\
\hline S. sonnei & $0.142 \pm 0.022$ & low-grade positive & $0.131 \pm 0.046$ & low-grade positive & 0 \\
\hline S. aureus & $3.22 \pm 0.088$ & highly positive & $0.6 \pm 0.058$ & low-grade positive & 81.36 \\
\hline N. gonorrhoeae & $0.361 \pm 0.014$ & low-grade positive & $0.215 \pm 0.023$ & low-grade positive & 40.44 \\
\hline P. aeruginosa & $0.409 \pm 0.076$ & low-grade positive & $0.084 \pm 0.016$ & negative & 79.46 \\
\hline V. cholerae & $0.032 \pm 0.002$ & negative & - & - & - \\
\hline
\end{tabular}

\subsection{Biofilm Inhibition}

Biofilm inhibitory activity of AuNPs was assessed on the strains that showed a biofilm formation potential on polystyrene surface.

According to Table 1, AuNPs showed great antibiofilm activity. On polystyrene, the percentage of biofilm inhibition ranged from 40.44 to $82.43 \%$. The greatest antibiofilm activity was detected from S. Typhimurium, which passed from low-grade positive to biofilm negative. In addition to $S$. aureus that changed from highly positive to and lowgrade positive and $P$. aeruginosa that changed from highly positive to biofilm negative. Moreover, the two low-grade positive E. faecalis and N. gonorrhoeae have conserved their initial biofilm phenotype despite the observed inhibition. However, AuNPs did not show any activity on E. coli and S. sonnei.

\subsection{Effect of AuNPs on GroES and GroEL Expression}

The expression level of GroES before and after treatment with AuNPs was analyzed using western blot (Figure 2a). Control cells showed that GroES was expressed in all tested bacteria with different degrees except for E. coli and V. cholerae. The very high and low expression levels of this protein were observed in S. typhimurium and S. sonnei, respectively.

Under the AuNPs effect, the analysis by Image-J (Figure 2b) demonstrated that the quantity of GroES protein was reduced in S. Typhimurium, B. cereus, S. aureus, and N. gonorrhoeae with percentages of $46.81 \%, 30.17 \%, 38.35 \%$, and $28.43 \%$, respectively. However, the amount of GroES protein was increased in S. sonnei (86.33\%) and P. aeruginosa (11.40\%). In addition, this protein remained stable in E. faecalis but was expressed in E. coli and V. cholerae.

Concerning GroEL (Figure 3a), the results showed that this protein was expressed with different degrees only in the non-treated S. Typhimurium, B. cereus, E. faecalis, S. aureus, and N. gonorrhoeae. 


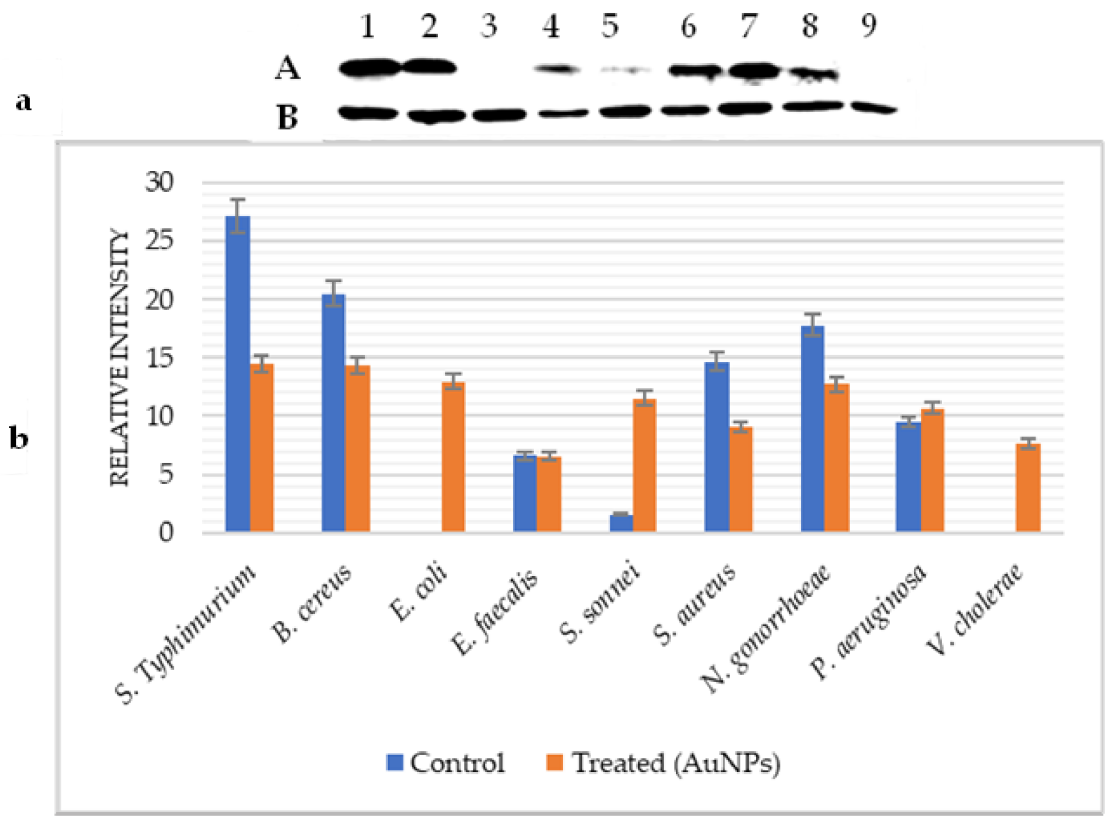

Figure 2. GroES heat shock protein expression under AuNPs effect. (a): Western blot analysis; (b): Image-J bands quantification; (A): Control; (B): Treated (AuNPs). S. Typhimurium (1), B. cereus (2), E. coli (3), E. faecalis (4), S. sonnei (5), S. aureus (6), N. gonorrhoeae (7), P. aeruginosa (8), and V. cholerae (9).

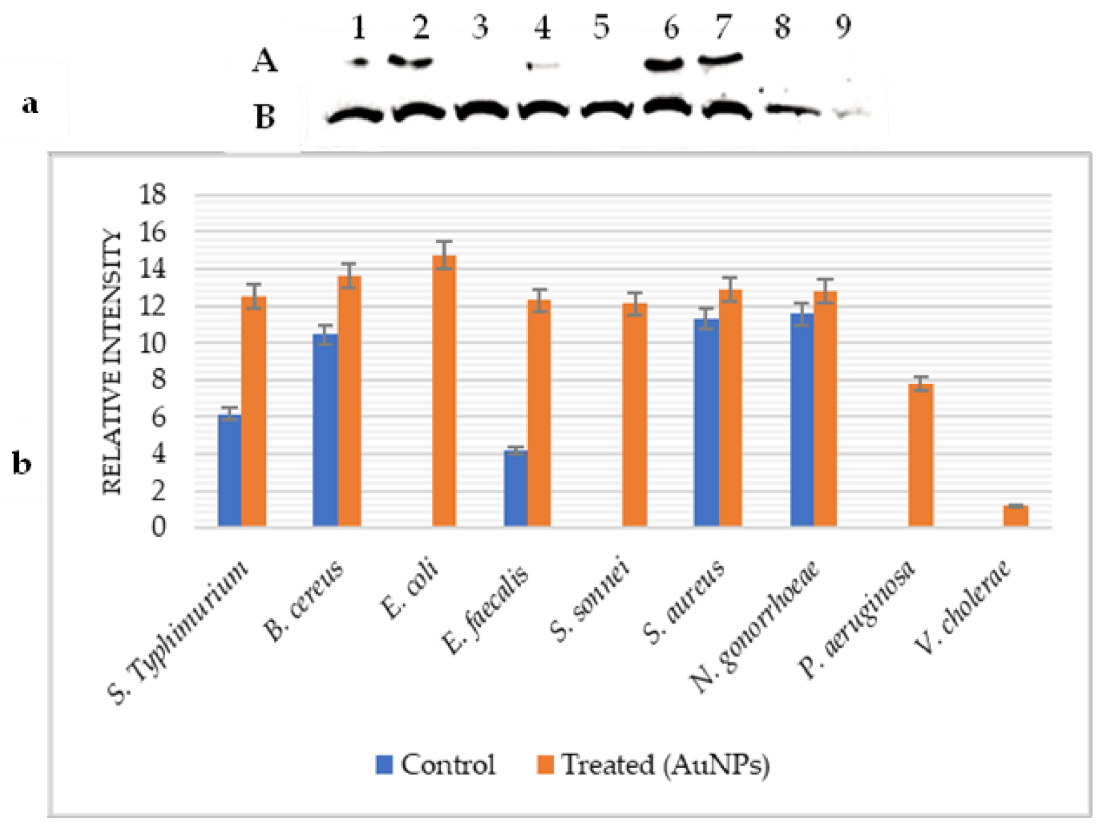

Figure 3. GroEl heat shock protein expression under AuNPs effect. (a): Western blot analysis; (b): Image-J bands quantification; (A): Control; (B): Treated (AuNPs) S. Typhimurium (1), B. cereus (2), E. coli (3), E. faecalis (4), S. sonnei (5), S. aureus (6), N. gonorrhoeae (7), P. aeruginosa (8), and V. cholerae (9).

After treatment with AuNPs, GroEL was induced in all tested bacteria. Its level of expression was considerably increased in E. faecalis (66.04\%), S. Typhimurium (50.83\%), and B. cereus $(23.35 \%)$. This Hsp was slightly induced in S. aureus $(12.5 \%)$ and $N$. gonorrhoeae $(9.64 \%)$. The very high and low expression levels of GroEL were detected in E. coli and $V$. cholerae, respectively (Figure $3 b$ ). 


\section{Discussion}

The increased resistance of pathogenic bacteria to antibiotics and the lack of new antibacterial drugs have prompted researchers to focus their efforts to explore nanotechnological measures against microbial infections for therapeutic applications. AuNPs have attracted considerable interest because of their promising applications in the development of novel antibacterial molecules [1]. This study investigates for the first time the effect of plasmonic gold nanoprisms on biofilm formation and GroEL/GroES proteins expression in some pathogenic bacteria as well as their antibacterial properties.

The antibacterial activity showed that AuNPs are effective against tested pathogenic bacteria. The MICs values varied from $50 \mu \mathrm{g} / \mathrm{mL}$, for S. typhimurium and V. cholerae, to $100 \mu \mathrm{g} / \mathrm{mL}$ for E. coli, E. faecalis, P. aeruginosa, S. aureus, B. cereus, S. sonnei, and N. gonorrhoeae. Accordingly, Gram-negative and Gram-positive bacteria react in the same way face to AuNPs. However, the study of Zawrah et al. [22] indicated that AuNPs are less effective against Gram-positive bacteria due to the nature of the cell wall. Nanoparticles, with a positive charge, attach with the negatively charged microorganisms by the electrostatic attraction in the cell wall membrane [23].

AuNPs characterized using TEM appear as equilateral triangular prisms with an average edge length of $150 \mathrm{~nm}$. Several reports have shown that smaller NPs have higher antibacterial activity [24-26]. Indeed, smaller particles affect the larger surface area of the bacteria, enter easily into the bacterial cell and affect the intracellular processes. Thereby they have more bactericidal activity than larger [27]. However, in this work, the triangular prisms of gold showed great antimicrobial property, despite their high length, against Grampositive and Gram-negative bacteria. This finding corroborates the data of Sohm et al. [28] showing that larger NPs are more effective and indicating that size alone is not the most important factor of their toxicity. The effectiveness of gold triangular nanoprisms may be due to their shape. According to Smitha and Gopchandran [29], the antibacterial properties of triangular AuNPs have shown better activity against Gram-positive and Gram-negative bacteria compared to spherical AuNPs, which indicates that the shape could play a significant role in the potential antibacterial activity of AuNPs.

Biofilm, as a major virulence factor, is responsible for about $80 \%$ of human infections, and the Gram-negative bacterium P. aeruginosa, E. coli, and the Gram-positive S. aureus are the most frequent [30]. Due to the resistance to antibiotics, the immune system, and the spread of infection, the treatment of biofilm becomes more complex [31]. Thereby, the discovering of novel therapeutic molecules, like plasmonic gold nanoprisms, to inhibit biofilm is of great importance. In this work, almost all of the tested bacteria were low-grade positive producers on polystyrene surfaces with OD570 values ranging from 0.119 to 0.599 . In addition, only $S$. aureus was a highly positive producer, while $B$. cereus and $V$. cholerae were not able to form biofilm. AuNPs showed great antibiofilm activity with the percentage of inhibition ranging from $40.44 \%$ for N. gonorrhoeae to $82.43 \%$ for S. typhimurium. Thereby, this nanoparticle could be a good alternative for the treatment of the formation of biofilm by pathogenic bacteria. Indeed, the penetration ability of AuNPs to get inside the biofilm and to disperse is of great importance as the biofilm layer provides an impermeable barrier to many antibiotics. Our results are in agreement with those of Singh et al. [32], who showed that AuNPs possess a remarkable reduction in the biofilm formation by P. aeruginosa and E. coli. The highest antibiofilm activity of AuNPs was observed in S. typhimurium and S. aureus that formed the strongest biofilm among the tested bacteria. However, this result is in discordance with the report of Ahmed et al. [33], who observed lower disruption of biofilms in the strong biofilm producer K. pneumoniae compared to the other isolates suggesting that the thickness and composition of biofilm play a key role in the penetration of AuNPs. This may be attributed to the shape of AuNPs as equilateral triangular prisms.

Hsps are key elements in the bacterial response to stress and environmental changes in order to maintain cell homeostasis in addition to their important role in pathogenesis [34]. GroEL/GroES play a major role in protein folding even during non-stressed growth conditions, although their action becomes more important during stress. In this 
work, we investigated the differential expression of GroEL and GroES under the effect of AuNPs. Firstly, before treatment, GroES was expressed with different levels in all tested bacteria except for E. coli and V. cholerae, but GroEL was expressed only in S. typhimurium, B. cereus, E. faecalis, S. aureus, and N. gonorrhoeae which indicates that GroES is more implicated in normal growth bacteria than GroEL. Under AuNPs effect, the amount of GroEL was considerably increased in all strains indicating that this protein plays an important role in maintaining the cell in such condition, which is in agreement with the report of Makumire et al. [35]. Thereby it can be considered as an AuNPs-inducible protein [36]. Concerning GroES, its production was increased only in S. sonnei and P. aeruginosa but was decreased or remained stable in other strains suggesting that this protein was altered or downregulated by AuNPs. According to Kustos et al. [37], under stress conditions such as nanoparticles, protein synthesis is inhibited, and cell division is interrupted. In parallel, the expression of various proteins increases; these are the so-called stress proteins as GroEL in this study. Knowing that the GroE machine is involved in protein folding and other mechanisms, the overexpression of GroEL may have served as compensation for the lack of GroES expression to maintain cell homeostasis. However, alteration observed in GroES expression may indicate that the GroE machine was altered, and thereby the protein folding mechanism of bacteria may be altered, which can explain the high activity of AuNPs.

\section{Materials and Methods}

\subsection{Bacterial Strains}

Nine (9) human pathogenic bacteria were tested in this work included: S. typhimurium (ATCC 1408), E. coli (ATCC 35218), S. sonnei (ATCC 25931), E. faecalis, P. aeruginosa PAO1, S. aureus (ATCC 25923), B. cereus (ATCC 11778), V. cholerae (ATCC 9459), and N. gonorrhoeae (ATCC 49226).

\subsection{Gold Nanoparticles}

\subsubsection{Synthesis}

To synthesize gold nanoparticles, a triethylene glycol reagent (ACROS Organics, 98\%) was used as a solvent. The precursor of gold was hydrogen tetrachloroaurate (III) trihydrate $\left(\mathrm{HAuCl}_{4} \cdot 3 \mathrm{H}_{2} \mathrm{O}\right.$; Sigma-Aldrich, St. Louis, $\mathrm{MO}$, USA). In addition, polyvinyl-pyrrolidone (PVP) (K30, Sigma-Aldrich) was used as a surfactant [21]. For the experiment, $25 \mathrm{~mL}$ of triethylene glycol suspension containing $0.038 \mathrm{mmol}$ of $\mathrm{HAuCl}_{4} \cdot 3 \mathrm{H}_{2} \mathrm{O}$ and a given quantity of PVP were heated at $150{ }^{\circ} \mathrm{C}$ for 30 min under shaking. The molar ratio of PVP to $\mathrm{HAuCl}_{4}$ $(\mathrm{R}(\mathrm{PVP} / \mathrm{Au}))$ was 0.05 . The formed gold particles and the final colloidal solution had a blue color. The product was centrifuged, washed many times with ethanol/acetone (2:1) solution, and scattered in ethanol.

\subsubsection{Characterization}

The morphological analysis of the gold particles was determined by transmission electron microscopy (TEM) (JEOL-JFC 1600). An elemental analysis was conducted using energy-dispersive X-ray spectrograph (EDX) attached to the TEM. The selected area electron diffraction (SAED) was also performed on the microscope. The Perkin-Elmer Lambda $11 \mathrm{UV} / \mathrm{VIS}$ spectrophotometer was used to determine the optical absorption spectra of diluted Au NPs solution.

\subsection{Antibacterial Activity of Au NPs: Minimum Inhibitory and Minimum Bactericidal Concentration}

MICs and MBCs were determined three times on 96-well microtiter plates (Nunc, Roskilde, Denmark) [38]. The bacterial inoculums (0.5 McFarland standards turbidity) were prepared from $12 \mathrm{~h}$ broth cultures. Then, a serial two-fold dilution of the AuNPs was prepared in $5 \mathrm{~mL}$ of nutrient broth with a concentration ranging from 0.012 to $7.2 \mathrm{mg} / \mathrm{mL}$.

The plates were prepared by adding $100 \mu \mathrm{L}$ from the AuNPs serial dilutions, $95 \mu \mathrm{L}$ of nutrient broth, and $5 \mu \mathrm{L}$ of the bacterial inoculum in each well. The negative control 
comprising $5 \mu \mathrm{L}$ of the inoculum and $195 \mu \mathrm{L}$ of nutrient broth without AuNPs was placed in the last well. The plates at a final volume of $200 \mu \mathrm{L}$ were then incubated at $37^{\circ} \mathrm{C}$ for 18-24 h.

The lowest concentration of the AuNPs at which the growth of the cells was inhibited was interpreted as MIC. However, the lowest concentration of AuNPs, required to kill $\geq 99.9 \%$ of the initial bacterial cells was interpreted as MBC and was determined by subculturing $20 \mu \mathrm{L}$ from clear wells of the MIC test on MHA [39].

\subsection{Biofilm Formation on Polystyrene}

The capacity of bacteria to form biofilm was evaluated by crystal violet assay using U-bottomed 96-well microtiter plates [40]. Each bacterium was investigated three times, and sterile TSB was served as control. An automated Multiskan reader (GIO. DE VITA E C, Rome, Italy) was used to measure the wells' optical density at $570 \mathrm{~nm}$ (OD570). Biofilm formation was defined as highly positive (OD570 $\geq 1)$, low-grade positive $(0.1 \leq$ OD570 $<1)$, or negative (OD570 <0.1).

\subsection{Biofilm Inhibition}

The capacity of AuNPs to prevent bacterial strains from forming biofilms was investigated. Experimentally, $100 \mu \mathrm{L}$ of AuNPs mixed in TSB ( $2 \%$ glucose) were placed in each well of a U-bottomed 96-well microtiter plate, along with $100 \mu \mathrm{L}$ of bacterial suspensions $\left(10^{8} \mathrm{CFU} / \mathrm{mL}\right)$. The final AuNPs concentrations were equivalent to the MIC, and the final volume per well was $200 \mu \mathrm{L}$. The experiments were carried out three times. Crystal violet was used to measure the formed biofilm after incubation of microplates at $37{ }^{\circ} \mathrm{C}$ for $24 \mathrm{~h} \mathrm{[41].} \mathrm{The} \mathrm{inoculum} \mathrm{volume} \mathrm{and} \mathrm{AuNPs} \mathrm{were} \mathrm{replaced} \mathrm{with} \mathrm{TSB} \mathrm{and} \mathrm{sterile} \mathrm{water}$ in the control wells, respectively. The percentage of biofilm inhibition was determined according to the formula described by Jadhav et al. [42].

$$
\% \text { Inhibition }=100-\left(\frac{\text { OD570 sample }}{\text { OD570 control }} \times 100\right)
$$

\subsection{Western Blot for GroEL and GroES Analysis}

Expression of GroEL and GroES under AuNPs conditions were analyzed using Western blot. For experiments, $11 \mu \mathrm{g}$ of whole-cell proteins (control and AuNPs treated bacteria) were analyzed by SDS-PAGE [43] and blotted onto nitrocellulose membranes (Millipore, Bedford, MA, USA). The membranes were blocked overnight at $4{ }^{\circ} \mathrm{C}$ in PBS-5\% skimmed milk, $0.1 \%$ Tween 20. The membranes were incubated for $1 \mathrm{~h}$ with anti-GroEL (Abcam, ab90522) and anti-GroES (Abcam, ab69823) polyclonal rabbit-antibodies were diluted to $1 / 1000$ and $1 / 5000$, respectively. Then, the membranes were incubated with a goat anti-rabbit IgG peroxidase-conjugated monoclonal antibody (Sigma, St Louis, MO, USA) diluted at $1 / 10,000$. The bound antibodies were visualized by ECL (GE Healthcare, Uppsala, Sweden). Western blots were analyzed with imaging (Image-J 1.50) to determine the intensity of each band [44].

\section{Conclusions}

The results developed in this work support the medical application of AuNPs as a therapeutic molecule for the treatment of infections caused by pathogenic bacteria. Plasmonic gold nanoprisms showed, for the first time, great antibacterial and antibiofilm activities against human pathogenic bacteria. In addition to the alteration observed in GroES expression as a part of GroE machine implicated in the bacterial protein folding mechanism. Despite their stability and low toxicity, the application of AuNPs needs more in vitro testing and in vivo clinical trials to establish their safety, efficacity, and possible adverse effects. 
Author Contributions: F.B.A. conceived and designed the experiments; F.B.A. and R.L. performed the experiments; A.M. the synthesis of AuNPs; O.M.A. funding acquisition; F.B.A. and R.L. writingreview and editing. All authors have read and agreed to the published version of the manuscript.

Funding: The Authors appreciated Taif University Researchers Supporting Project number (TURSP2020/262), Taif University, Taif, Saudi Arabia.

Institutional Review Board Statement: Not applicable.

Informed Consent Statement: Not applicable.

Data Availability Statement: Data is contained within the article.

Acknowledgments: The authors are thankful to Taif University for supplying essential facilities and acknowledge the support of Taif University Researchers Supporting Project number (TURSP2020/262), Taif University, Taif, Saudi Arabia.

Conflicts of Interest: The authors declare no conflict of interest.

\section{References}

1. Katas, H.; Lim, C.; Nor Azlan, A.; Buang, F.; Mh Busra, M. Antibacterial activity of biosynthesized gold nanoparticles using biomolecules from lignosus rhinocerotis and chitosan. Saudi. Pharm. J. 2019, 27, 283-292. [CrossRef] [PubMed]

2. Rossolini, G.; Arena, F.; Pecile, P.; Pollini, S. Update on the antibiotic resistance crisis. Curr. Opin. Pharmacol. 2014, 18, 56-60. [CrossRef]

3. Li, X.; Robinson, S.; Gupta, A.; Saha, K.; Jiang, Z.; Moyano, D.; Sahar, A.; Riley, M.; Rotello, V. Functional gold nanoparticles as potent antimicrobial agents against multi-drug-resistant bacteria. ACS. Nano. 2014, 8, 10682-10686. [CrossRef]

4. Lenchenko, E.; Blumenkrants, D.; Sachivkina, N.; Shadrova, N.; Ibragimova, A. Morphological and adhesive properties of Klebsiella pneumoniae biofilms. Vet. World. 2020, 13, 197-200. [CrossRef] [PubMed]

5. Brady, R.; Leid, J.; Calhoun, J.; Costerton, J.; Shirtliff, M. Osteomyelitis and the role of biofilms in chronic infection. FEMS. Immunol. Med. Microbiol. 2008, 52, 13-22. [CrossRef] [PubMed]

6. Römling, U.; Balsalobre, C. Biofilm infections, their resilience to therapy and innovative treatment strategies. J. Intern. Med. 2012, 272, 541-561. [CrossRef]

7. Hall-Stoodley, L.; Costerton, J.W.; Stoodley, P. Bacterial biofilms: From the natural environment to infectious diseases. Nat. Rev. Microbiol. 2004, 2, 95-108. [CrossRef]

8. Simões, M.; Bennett, R.N.; Rosa, E.A.S. Understanding antimicrobial activities of phytochemicals against multidrug resistant bacteria and biofilms. Nat. Prod. Rep. 2009, 26, 746-757. [CrossRef] [PubMed]

9. Stewart, P.S. Mechanisms of antibiotic resistance in bacterial biofilms. Int. J. Med. Microbiol. 2002, 292, 107-113. [CrossRef]

10. Vinod Kumar, K.; Lall, C.; Vimal Raj, R.; Vedhagiri, K.; Kartick, C.; Surya, P.; Natarajaseenivasan, K.; Vijayachari, P. Overexpression of heat shock groel stress protein in Leptospiral biofilm. Microb. Pathog. 2017, 102, 8-11. [CrossRef]

11. Stamm, L.; Gherardini, F.; Parrish, E.; Moomaw, C. Heat shock response of spirochetes. Infect. Immun. 1991, 59, 1572-1575. [CrossRef]

12. Susin, M.; Baldini, R.; Gueiros-Filho, F.; Gomes, S. GroES/GroEL and Dnak/Dnaj have distinct roles in stress responses and during cell cycle progression in Caulobacter crescentus. J. Bacteriol. 2006, 188, 8044-8053. [CrossRef]

13. Maleki, F.; Khosravi, A.; Nasser, A.; Taghinejad, H.; Azizian, M. Bacterial heat shock protein activity. J. Clin. Diagn. Res. 2016, 10, BE01-BE03. [CrossRef]

14. Gomes, S.L.; Simaõ, R.C.G. Stress response: Heat. In Encyclopedia of Microbiology; Schaechter, M., Ed.; Elsevier Academic Press: Oxford, UK, 2009; pp. 464-474.

15. Yafout, M.; Ousaid, A.; Khayati, Y.; El Otmani, I. Gold nanoparticles as a drug delivery system for standard chemotherapeutics: A new lead for targeted pharmacological cancer treatments. Sci. Afr. 2021, 11, e00685. [CrossRef]

16. Thambiraj, S.; Hema, S.; Ravi Shankaran, D. Functionalized gold nanoparticles for drug delivery applications. Mater. Today Proc. 2018, 5, 16763-16773. [CrossRef]

17. Kong, F.; Zhang, J.; Li, R.; Wang, Z.; Wang, W.; Wang, W. Unique roles of gold nanoparticles in drug delivery, targeting and imaging applications. Molecules 2017, 22, 1445. [CrossRef] [PubMed]

18. Zhang, L.; Gu, F.; Chan, J.; Wang, A.; Langer, R.; Farokhzad, O. Nanoparticles in medicine: Therapeutic applications and developments. Clin. Pharmacol. Ther. 2008, 83, 761-769. [CrossRef] [PubMed]

19. Kandi, V.; Kandi, S. Antimicrobial properties of nanomolecules: Potential candidates as antibiotics in the era of multi-drug resistance. Epidemiol. Health 2015, 37, e2015020. [CrossRef] [PubMed]

20. Chhibber, S.; Nag, D.; Bansal, S. Inhibiting biofilm formation by Klebsiella pneumoniae B5055 using an iron antagonizing molecule and a bacteriophage. BMC Microbiol. 2013, 13, 174. [CrossRef]

21. Mezni, A.; Dammak, T.; Fkiri, A.; Mlayah, A.; Abid, Y.; Smiri, L.S. Photochemistry at the surface of gold nanoprisms from surface-enhanced raman scattering blinking. J. Phys. Chem. C 2014, 118, 17956-17967. [CrossRef] 
22. Zawrah, M.F.; AbdEl-Moez, S.I. Antimicrobial activities of gold nanoparticles against major foodborne pathogens. Life Sci. 2011, 8, 37-44.

23. Dibrov, P.; Dzioba, J.; Gosink, K.; Häse, C. Chemiosmotic mechanism of antimicrobial activity of ag + in Vibrio cholerae. Antimicrob. Agents Chemother. 2002, 46, 2668-2670. [CrossRef] [PubMed]

24. Penders, J.; Stolzoff, M.; Hickey, D.; Andersson, M.; Webster, T. Shape-dependent antibacterial effects of non-cytotoxic gold nanoparticles. Int. J. Nanomed. 2017, 12, 2457-2468. [CrossRef] [PubMed]

25. Cheon, J.Y.; Kim, S.J.; Rhee, Y.H.; Kwon, O.H.; Park, W.H. Shape-dependent antimicrobial activities of silver nanoparticles. Int. J. Nanomed. 2019, 14, 2773-2780. [CrossRef] [PubMed]

26. Cui, L.; Chen, P.; Chen, S.; Yuan, Z.; Yu, C.; Ren, B.; Zhang, K. In situ study of the antibacterial activity and mechanism of action of silver nanoparticles by surface-enhanced Raman spectroscopy. Anal. Chem. 2013, 85, 5436-5443. [CrossRef]

27. Shrivastava, S.; Bera, T.; Roy, A.; Singh, G.; Ramachandrarao, P.; Dash, D. Characterization of enhanced antibacterial effects of novel silver nanoparticles. Nanotechnology. 2007, 18, 225103. [CrossRef]

28. Sohm, B.; Immel, F.; Bauda, P.; Pagnout, C. Insight into the primary mode of action of tio2 nanoparticles on Escherichia coli in the dark. Proteomics. 2014, 15, 98-113. [CrossRef]

29. Smitha, S.L.; Gopchandran, K.G. Surface Enhanced Raman scattering, antibacterial and antifungal active triangular gold nanoparticles. Spectrochim. Acta A Mol. Biomol. Spectrosc. 2013, 102, 114-119. [CrossRef]

30. Joo, H.-S.; Otto, M. Molecular basis of in vivo biofilm formation by bacterial pathogens. Chem. Biol. 2012, 19, 1503-1513. [CrossRef]

31. Paharik, A.E.; Horswill, A.R. The Staphylococcal Bioflm: Adhesins, Regulation, and Host Response. Microbiol. Spectr. 2016, 4, 10. [CrossRef]

32. Singh, P.; Pandit, S.; Beshay, M.; Mokkapati, V.R.S.S.; Garnaes, J.; Olsson, M.E.; Sultan, A.; Mackevica, A.; Mateiu, R.V.; Lütken, H.; et al. Anti-biofilm effects of gold and silver nanoparticles synthesized by the rhodiola rosea rhizome extracts. Artif. Cells. Nanomed. Biotechnol. 2018, 46, S886-S899. [CrossRef]

33. Ahmed, A.; Khan, A.K.; Anwar, A.; Ali, S.A.; Shah, M.R. Biofilm inhibitory effect of chlorhexidine conjugated gold nanoparticles against Klebsiella pneumoniae. Microb. Pathog. 2016, 98, 50-56. [CrossRef]

34. Bohne, J.; Sokolovic, Z.; Goebel, W. Transcriptional regulation of PRFA and PRFA-regulated virulence genes in listeria monocytogenes. Mol. Microbiol. 1994, 11, 1141-1150. [CrossRef] [PubMed]

35. Makumire, S.; Revaprasadu, N.; Shonhai, A. Dnak protein alleviates toxicity induced by citrate-coated gold nanoparticles in Escherichia coli. PLoS ONE 2015, 10, e0121243.

36. Ben Abdallah, F.; Ellafi, A.; Lagha, R.; Bakhrouf, A.; Namane, A.; Rousselle, J.-C.; Lenormand, P.; Kallel, H. Identification of outer membrane proteins of Vibrio parahaemolyticus and Vibrio alginolyticus altered in response to $\gamma$-irradiation or long-term starvation. Res. Microbiol. 2010, 161, 869-875. [CrossRef] [PubMed]

37. Kustos, I.; Kocsis, B.; Kilár, F. Bacterial outer membrane protein analysis by electrophoresis and microchip technology. Expert Rev. Proteomics 2007, 4, 91-106. [CrossRef]

38. Bagamboula, C.; Uyttendaele, M.; Debevere, J. Inhibitory effect of thyme and basil essential oils, carvacrol, thymol, estragol, linalool and p-cymene towards Shigella sonnei and S. flexneri. J. Food Microbiol. 2004, 21, 33-42. [CrossRef]

39. El-Deeb, B.; Elhariry, H.; Mostafa, N.Y. Antimicrobial Activity of Silver and Gold Nanoparticles Biosynthesized Using Ginger Extract. Res. J. Pharm. Biol. Chem. Sci. 2016, 7, 1085.

40. Gulluce, M.; Sahin, F.; Sokmen, M. Antimicrobial and antioxidant properties of the essential oils and methanol extract from Mentha longifolia L. Food. Chem. 2007, 103, 1449-1456. [CrossRef]

41. Oulkheir, S.; Aghrouch, M.; El Mourabit, F.; Dalha, F.; Graich, H.; Amouch, F.; Ouzaid, K.; Moukale, A.; Chadli, S. Antibacterial Activity of Essential Oils Extracts from Cinnamon, Thyme, Clove and Geranium Against a Gram Negative and Gram-Positive Pathogenic Bacteria. J. Dis. Med. Plants 2017, 3, 1-5. [CrossRef]

42. Jadhav, S.; Shah, R.; Bhave, M.; Palombo, E.A. Inhibitory activity of yarrow essential oil on Listeria planktonic cells and biofilms. J. Food Control 2013, 29, 125-130. [CrossRef]

43. Laemmli, U.K. Cleavage of structural proteins during the assembly of the head of bacteriophage t4. Nature 1970, 227, 680-685. [CrossRef] [PubMed]

44. Gasmi, N.; Ayed, A.; Ammar, B.; Zrigui, R.; Nicaud, J.-M.; Kallel, H. Development of a cultivation process for the enhancement of human interferon alpha $2 b$ production in the oleaginous yeast, Yarrowia Lipolytica. Microb. Cell. Factories 2011, 10, 90. [CrossRef] [PubMed] 